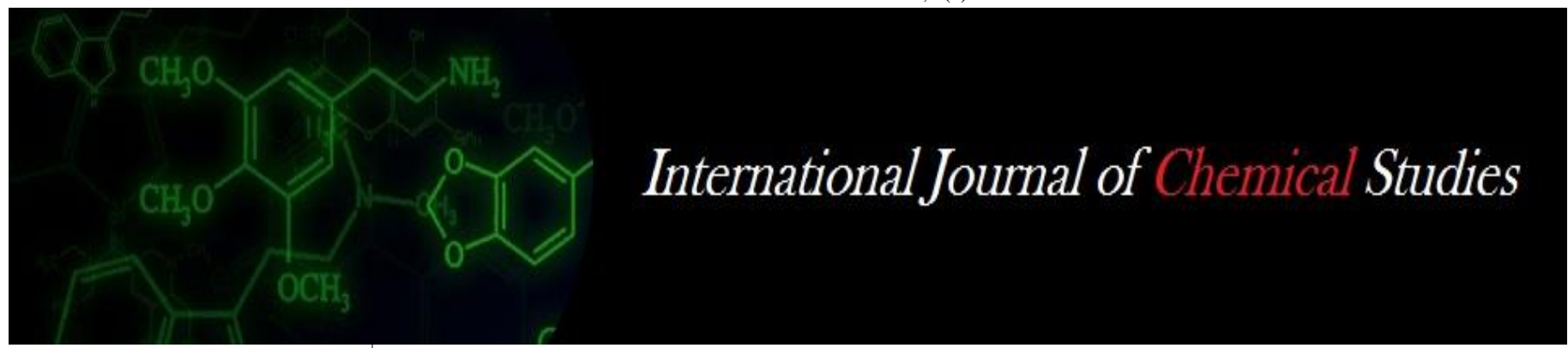

P-ISSN: 2349-8528

E-ISSN: 2321-4902

www.chemijournal.com

IJCS 2020; 8(3): 866-869

(C) 2020 IJCS

Received: 07-03-2020

Accepted: 08-04-2020

S Shailja Iyer

Department of Soil Science and Agricultural Chemistry, College of Agriculture, IGKV, Raipur,

Chhattisgarh, India

GP Ayam

Department of Soil Science and Agricultural Chemistry, College of Agriculture, IGKV, Raipur,

Chhattisgarh, India
Corresponding Author:

S Shailja Iyer

Department of Soil Science and Agricultural Chemistry, College of Agriculture, IGKV, Raipur, Chhattisgarh, India

\section{Soil fertility status of available potassium in soil through soil fertility mapping using GPS and GIS techniques of Dharmaur micro-watershed Jagdalpur block, Bastar district of (C.G.) state}

\section{S Shailja Iyer and GP Ayam}

DOI: https://doi.org/10.22271/chemi.2020.v8.i3k.9309

\begin{abstract}
The present research on the soil fertility status of available potassium in soil by soil fertility mapping using GPS and GIS techniques of the Dharmaurmicro watershed Jagdalpur block, Bastar district of C.G. was conducted during 2017-18. The focus here was to prepare soil fertility mapping using GPS and GIS techniques. We quantified the available potassium in the soils of the study area using GPS-based grid samples and created soil fertility maps using geostatistical methods. A total of 382 soil samples were collected from the area covering most of Dharmaur, Kumhrawand and Tekameta villages and the study area is surrounded by Kumhrawand village to the East, Tekameta village to the West, Indravati river to the North and Bhadisgaon \& Biringpal villages to the South.
\end{abstract}

Keywords: Soil fertility mapping, GPS, GIS

\section{Introduction}

Soil fertility be defined while the capability of soil in the direction of contribute nutrients to the plants in an sufficient amount, suitable quantity, and free from toxic elements. Thus a fertile soil may or may not be abundant depending leading crops, marketing condition in addition to several further factors (i.e., excessive acidity or alkalinity, the presence of toxic substance, deprived physical properties or an excess or deficit of water. However, every productive soil have to be fertile. Now a days GIS and GPS techniques are extensively used for assemble soil fertility maps which is a computer-based software system which stores, analysis, and displays spatial data variability in maps and become a powerful tool and mechanism of precision farming._Potassium's unique function is as a regulator of metabolic activities. It is the only nutrient which remains in the plant fluids in a soluble state. In some plants, more is required than any other soil nutrient. Potassium is highly mobile in the soil, but leaching is minimized by cation exchange and by trapping within clay crystals. Potassium is the Great Regulator. It is active in numerous enzyme systems which control metabolic reactions, particularly in the synthesis of proteins and starches. Micronutrients, which have similar functions, are required only in minute amounts. In contrast, potassium must be present in large quantities, although it seems to be completely unsuited for its role. (D.K DAS, 2016) [4].

\section{Material and methods}

\section{Study Area}

Chhattisgarh state is divided into 3 Agro-climatic zones - Chattisgarh plains, Bastar Plateau, and Northern Hill zone, each covering 51\%, 28\%, and $21 \%$ of the total geographical area respectively. Bastar district comes under the Bastar Plateau zone. The study area is the Dharmaur Micro-Watershed in Jagdalpur block, Bastar District of Chhattisgarh state, which is located between $19^{\circ} 2^{\prime} 30^{\prime \prime}$ to $19^{\circ} 07^{\prime} 30^{\prime \prime} \mathrm{N}$ latitude and $81^{\circ} 55^{\prime}$ to $81^{\circ} 57^{\prime} 30^{\prime \prime}$ E longitude with an altitude of ranging from 540-562 $\mathrm{m}$ above MSL. The study area covers the majority of the part of Dharmaur, Kumhrawand and Tekameta villages and is surrounded by Kumhrawand village to the East, Tekameta village to the West, Indravati River to the North, and Bhadisgaon \& Biringpal villages to the South. 


\section{District Profile}

Bastar district is situated in the southern part of Chhattisgarh state, at the height of 550 meters above mean sea level. Bastar is surrounded by Kanker to the north, Dantewada to the west, Nowrangpur to the East and Sukma to the South. The area covered by forest in Bastar is $7112 \mathrm{sq} \mathrm{km}$, which is more than $75 \%$ of the total area of the district.

\section{Agro-ecological region}

The study area falls under Garjat Hills, Dandakaranya and the Eastern Ghats, hot moist sub-humid ESR, with deep loamy red and lateritic soils, low to medium AWC and LGP 180-210 days with average annual rainfall $1295 \mathrm{~mm}$ out of which $70 \%$ rainfall occurs during June-September.

\section{Soils of Bastar}

The soil seen in the Bastar district is mainly laterite soil. Soils of red and yellow shades could also be found in patches in a few places of the district. The trap rocks occur over the slopes in the Abujhmar tract, where thin light shaded soil is seen. The beds of streams and rivers like Indravati, Godavari, and Mahanadi have fresh alluvial soil. The texture of the soil ranges from sandy to fine textured (clayed soil). The $\mathrm{pH}$ of the soil varies from 4.5 to 6.5 (slightly acidic) in Sal forest areas and 5.5 to 7.8 (slightly basic) in teak forest areas, while other forests generally tend to have intermediate values. Despite the frequent summer fires, the percentage of the organic matter in the top layer of the soil is generally quite high, varying from 0.5 to $2.5 \%$.

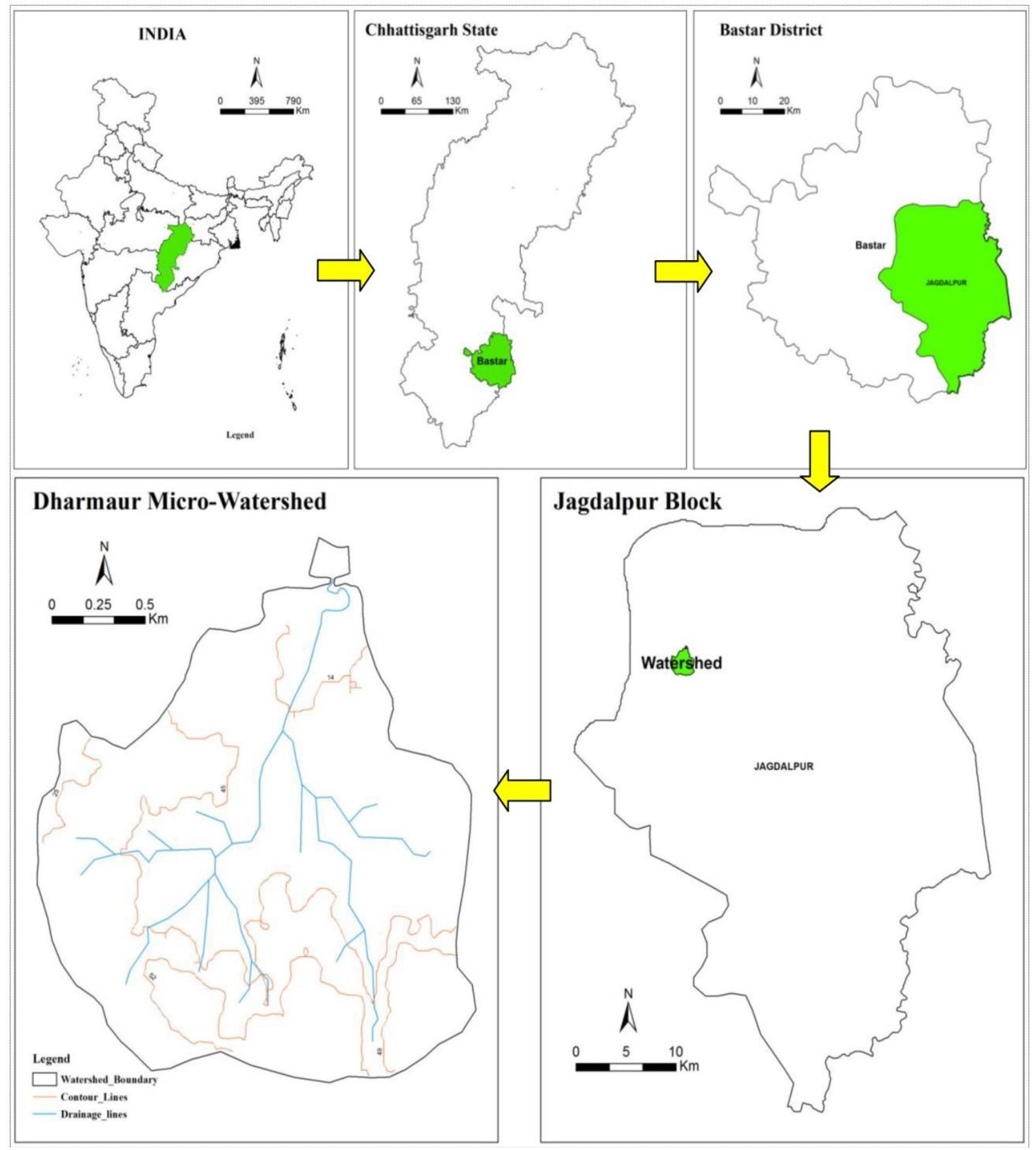

Fig 1: Location Map of the Dharmaur Micro-Watershed in Bastar district

\section{Method of Estimation of Available Potassium in Soil}

Take 5 gram of soil was shaken with $25 \mathrm{ml}$ of neutral normal ammonium acetate solution as an extractant in $250 \mathrm{ml}$ conical flask for 30 minutes and then filtered through Whatman number 40 filter paper. The amount of potassium present in the extract was determined by flame photometer as described by Black (1965). The results were calculated as $\mathrm{K} \mathrm{kg} / \mathrm{ha}$. 


\section{Result and discussion}

Available Potassium

The accessible K content Table 4.7.3, of Dharmaur microwatershed soils, ranged from 180.5 to $404.5 \mathrm{~kg} \mathrm{ha}^{-1}$ with an average value of $311.3 \mathrm{~kg} \mathrm{ha}^{-1}$. Given the soil test rating for available $\mathrm{K}\left(<135 \mathrm{kgha}^{-1}\right.$ as low, $135-335 \mathrm{kgha}^{-1}$ as average in addition to $>335 \mathrm{kgha}^{-1}$ as high in the status of $\mathrm{K}$ ) the soils of fall under medium and high status in available $\mathrm{K}$ content. In general, out of 382 samples, $69.1 \%$ of samples were medium in $\mathrm{K}$ status, and $30.8 \%$ were high in $\mathrm{K}$ status. The nutrient index value of available potassium in the soil of the study area falls under the medium category. Status of available $\mathrm{K}$ in soils of the study area shown in the form of soil fertility map in Fig. 2 Similar result is reported by Parvaiz Ahmad Lone (2016) noted that a total of 23 composite soil samples were gathered and classified into small, medium, high altitude soil differences in the estimated chemical parameters based on environmental circumstances altitude aspect. All soils were medium in available potassium in the Himalayan district of Kashmir.

The distribution of available $\mathrm{K}$ in different farming situation in the map shows that in Marhan, Tikra, Mal and Gabhar farming situation available $\mathrm{K}$ in soil were medium status and some part of Mal and Gabhar available $\mathrm{K}$ were high status in soil. Distribution of available K status in the study area shown in Table 1

Table 1: Distribution of available K status in the soils of the study area

\begin{tabular}{|c|c|c|c|c|}
\hline Available K kg ha $^{-\mathbf{1}}$ & No. of Samples & \% Samples & Nutrient Index & Fertility Rating \\
\hline Low $(<135)$ & Nil & Nil & \multirow{2}{*}{2.30} & \multirow{2}{*}{ Medium } \\
\hline Medium(135-335) & 264 & 69.1 & & \\
\hline High $(>335)$ & 118 & 30.8 & & \\
\hline
\end{tabular}

\section{Available Potassium (Kg/ha)}

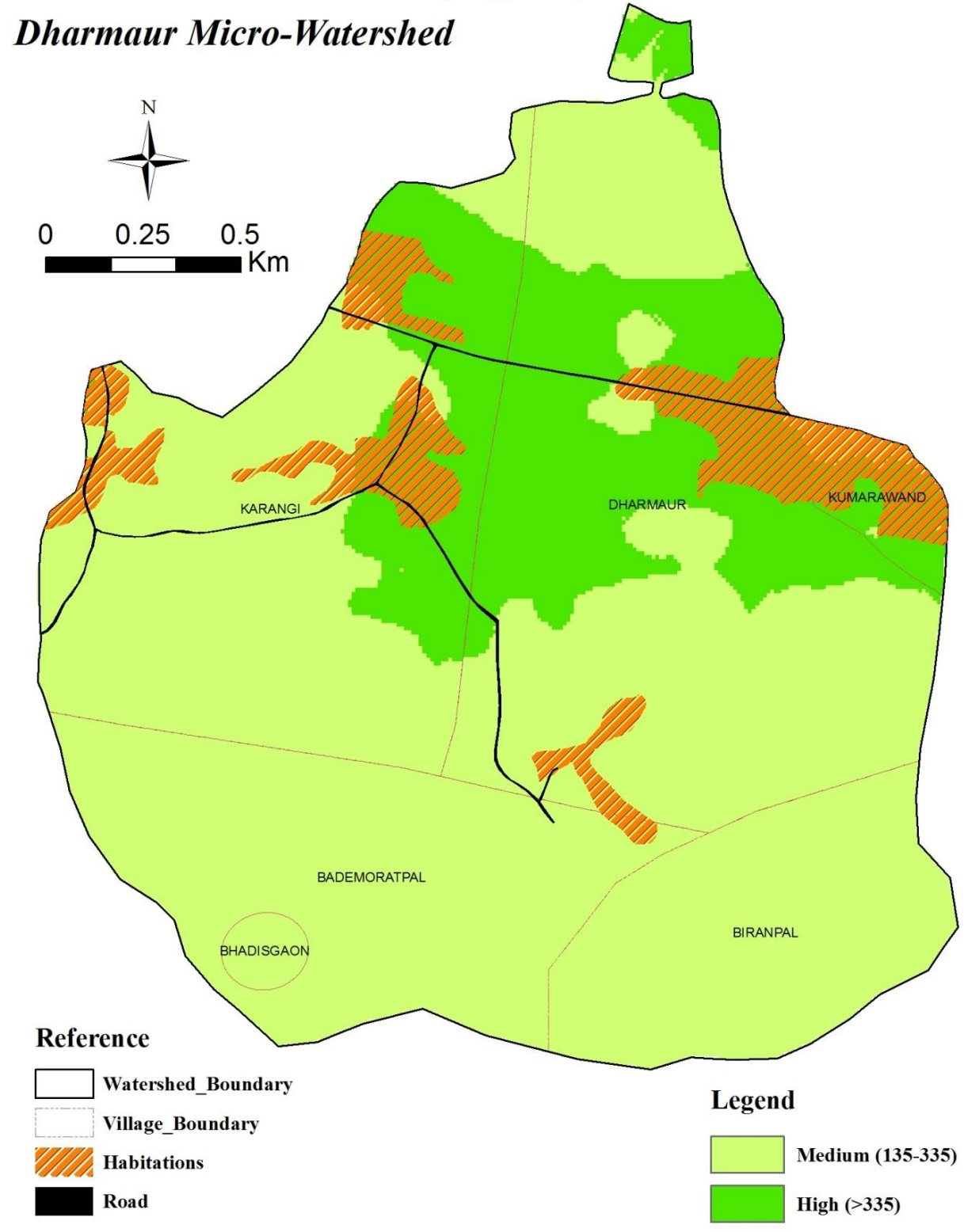

Fig 2: Status of available K in soils of Dharmaur micro-watershed 


\section{Descriptive statistics analysis}

The descriptive statistics of available Potassium are shown in Table 2 which suggested that they were all normally distributed. The science that deals with the compilation, evaluation and interpretation of numerical information (Corxton \& Cowden, 1969). This method summarizes both statistically and graphically data. It measures central of tendency of all soil parameters. The method offers a wide range of statistical data about a single variable. A logarithmic transformation is considered where the coefficient of skewness is greater than one (Webster and Oliver, 2001) ${ }^{[5]}$.

Table 2: Descriptive statistics of Available K (0-15 cm) depth of 382 soil Samples

\begin{tabular}{|c|c|}
\hline Descriptive Statistics & $\mathbf{K}(\mathbf{K g} / \mathbf{h a})$ \\
\hline Minimum & 180.5 \\
\hline Maximum & 404.5 \\
\hline 1st Quartile & 181.28 \\
\hline Median & 304.51 \\
\hline 3rd Quartile & 356.5 \\
\hline Mean & 311.3 \\
\hline Standard deviation & 55.73 \\
\hline Skewness & -0.12 \\
\hline
\end{tabular}

\section{References}

1. Agriculture Contingency Plan for District: Bastar by CRIDA Source: Agricultural Statistics, Commissioner land records, Raipur, Govt. of Chhattisgarh, 2009.

2. Devdas Deepika. Soil fertility mapping and tracing out limiting nutrients as production constraints for Gariyaband district of Chhattisgarh Ph.D thesis, I.G.K.V. Raipur, (Chhattisgarh), 2016.

3. Das DK. Introductory Soil Science. Kalyani Publishers, Ludhiana, 2004, 493.

4. Das. Soil fertility mapping of Nayranpur through GPS and GIS, 2016.

5. Webster R, Oliver MA. Geostatistics for Environmental Scientists. Hoboken, N.J.: John Wiley and Sons Inc, 2001. 